\title{
André Louco, de Bernardo Élis, sob a Ótica de Rosa Berardo
}

\author{
André Louco, by Bernardo Élis, \\ under Rosa Berardo's perspective
}

\author{
João Vitor de Souza-Ramos* \\ Ewerton de Freitas Ignácio** \\ Maria Eugênia Curado***
}

\footnotetext{
"Graduando em Letras pela Universidade Estadual de Goiás (UEG|UnUCSEH). E-mail: souzaramos.ctt@gmail.com

${ }^{* *}$ Doutor em Literaturas de Língua Portuguesa pela Universidade Estadual Paulista. Docente nos Programas de Pós-Graduação TECCER - Territórios e Expressões Culturais no Cerrado e POSLLI - Língua, Literatura e Interculturalidade da Universidade Estadual de Goiás. E-mail: ewerton.ignacio@ueg.br

"*** Doutora em Comunicação e Semiótica pela Pontifícia Universidade Católica de São Paulo. Docente no Programa de Pós-Graduação Interdisciplinar em Educação, Linguagem e Tecnologias (IELT) da Universidade Estadual de Goiás. E-mail: curadoeugenia@hotmail.com

TradTerm, São Paulo, v.38, fevereiro/2021, p. 291-314

Número Especial - III JOTA 
Resumo: Concebendo a arte literária e a arte cinematográfica como expressão humana e espelho do ser social e político, o presente artigo tem o objetivo de analisar como a tradução cinematográfica de Rosa Berardo, André Louco (1990), dialoga com a novela homônima de Bernardo Élis (1978). Sobremaneira, nos conflitos miméticos responsáveis por disparar o mecanismo do bode expiatório girardiano. Trata-se de uma pesquisa com ênfase na tradução intersemiótica, de Julio Plaza (2003), verticalizada com uma análise das relações sociais, proposta por Girard (2004). Elucidando, assim, o processo de transmutação e composição do foco narrativo conduzido pela ótica de Berardo.

Palavras-chave: Tradução Intersemiótica; Bode expiatório; Bernardo Élis; Rosa Berardo; André Louco.

Abstract: Conceiving literary and cinematographic art as an expression of human and a mirror of social and political being, this study aims to analyze how Rosa Berardo's film translation, André Louco (1990), dialogues with the homonymous novel by Bernardo Élis (1978). Especially in the mimetic conflicts responsible for triggering the Scapegoat mechanism. It is a research with an emphasis on intersemiotic translation, by Julio Plaza (2003), verticalized with an analysis of social relations, proposed by Girard (2004), elucidating the process of transmutation and composition of the narrative focus conducted by Berardo's perspective.

Keywords: Intersemiotic Translation; Scapegoat; Bernardo Élis, Rosa Berardo; André Louco. 


\title{
1. Introdução
}

A elaboração de uma adaptação cinematográfica caracteriza-se pela ressignificação de signos entre linguagens, criando uma obra originária a partir de uma (re)leitura e cotejamento seletivo, de forma que "o signo estético, quando é traduzido por outro signo estético, mantém com este uma conexão por similaridade" (PLAZA 2003: 32), estabelecendo uma "relação íntima com seu original, ao qual deve sua existência" (Ibid.). Todavia, esse processo independe de fidelidade à obra original, apresentando múltiplas configurações e intencionalidades que se remontam segundo as dinâmicas de cada mídia e autor. Assim,

\begin{abstract}
os signos empregados têm tendência a formar novos objetos imediatos, novos sentidos e novas estruturas que [...] tendem a se desvincular do original. A eleição de um sistema de signos, portanto, induz a linguagem a tomar caminhos e encaminhamentos inerentes à sua estrutura. [...] Nessa medida, a tradução intersemiótica induz [...] à descoberta de novas realidades, visto que "na criação de uma nova linguagem não se visa simplesmente uma outra representação de [...] conteúdos já pré-existentes [...], mas a criação de novas realidades, de novas formas-conteúdo" (PIGNATARI 1975: 161 apud PLAZA 2003: 30).
\end{abstract}

Isso significa que a adaptação é uma interpretação passível de redefinir os valores e o sentido da experiência narrativa, utilizando-se de recursos semióticos próprios de sua mídia para (re)criar uma obra; dialogando com o original, mas sem a obrigatoriedade de replicá-lo. Dessa forma, os estudos de tradução intersemiótica não devem se ater à ideia de 'traição' e 'fidelidade', mas à compreensão do diálogo latente no processo de recriação e transmutação sígnica.

Segundo Roman Jakobson (2015: 65, grifos do autor), a "tradução intersemiótica ou transmutação consiste na interpretação dos signos verbais por meio de sistemas de signos não-verbais". Apoiando-se no conceito de intersemiose de Jakobson e nos estudos de Charles Peirce e Walter Benjamin, Plaza entende a tradução intersemiótica como "transação criativa entre diferentes linguagens ou sistemas de signos" (apud AMORIM 2013: 18), não ocorrendo relações de equivalência nesse processo, pois a transmutação parte de um ato criativo que concebe um novo original, explorando diferentes TradTerm, São Paulo, v.38, fevereiro/2021, p. 291-314

Número Especial - III JOTA www.revistas.usp.br/tradterm 
signos, objetivos e estratégias narrativas. Portanto, os processos de "leitura, tradução, crítica e análise são operações simultâneas, embutidas/ou paralelas que serão sintetizadas na tradução" (PLAZA 2003: 30).

Tendo em vista que "a cultura contemporânea é sobretudo visual" (PeLLEGRINI 2003: 15), a tradução cinematográfica de uma obra literária atua como um expoente orgânico do texto original, fomentando novos leitores ao alcançar espaços e públicos que tangenciam o ambiente literário, seja pelo caráter imagético de 'consumo passivo' (e gama de estímulos sensoriais do audiovisual) ou por construtos socioculturais. Fato é que a tradução entre mídias, independente da lógica de mercado, gera debates e discussões, corroborando com pesquisas e análises teóricas. Dessa forma, os estudos comparados, como nos informa Carvalhal (2006), amparam o imbricamento entre diferentes linguagens e áreas do saber, possibilitando aproximações entre textos literários e narrativas cinematográficas sob múltiplas perspectivas.

Para analisar as obras, utilizar-se-á como referencial teórico o conceito de tradução intersemiótica, de Julio Plaza (2003), complementado pelos estudos de Xavier (2003) e o mecanismo do bode expiatório, de René Girard (2004).

Abarcando uma metodologia de caráter qualitativo e natureza analítico-descritiva, sob a esteira do comparativismo, a investigação ocupa-se da interpretação dos fenômenos e atribuição de significados (BRASILEIRO 2013), dividindo-se em dois momentos:

(1) discussão do texto literário;

(2) análise da tradução cinematográfica em diálogo.

Assim, concebendo a arte literária e a arte cinematográfica como expressão humana e espelho do ser social e político, propomos enriquecer o debate por meio de uma análise girardiana das interações sociais, nos embasando no Desejo Mimético (GIRARD 2009; KIRWAN 2015), que elucida a origem e criação de bodes expiatórios (GIRARD 2012: 88) ao desvendar a dimensão da mímesis do desejo como um dos elementos estruturantes da 
violência (HAMERTON-Kelly 2012: 58). ${ }^{1}$ Essa discussão justifica-se por esclarecer um dos pontos centrais de ambas as obras, contribuindo para o debate da transmutação e composição do foco narrativo.

O fenômeno do bode expiatório será analisado a partir dos estereótipos persecutórios do mecanismo vitimário (GIRARD 2004: 19-32), sendo estes: a (i) Crise Indiferenciadora; o (ii) Crime Indiferenciador; as (iii) Marcas Vitimárias; e a (iv) Violência ou Expulsão Coletiva (simbólica ou física, lançando à vítima a responsabilidade sobre a crise).

\section{André Louco e a narrativa de Bernardo Élis}

Com uma narrativa permeada pela realidade humana e social, tendo como palco o Brasil Central, Ermos e Gerais marca, em 1944, a estreia de Bernardo Élis - livro composto por dezenove contos e a novela André Louco (1978). ${ }^{2}$

Situada em um contexto de agitações e conflitos, a obra estrutura-se em um interregno marcado por lutas entre o velho e o novo, construindo um registro da cultura e identidade rural que engatinhava em seu processo de urbanização. Élis assume a forma do conto e rompe com a tradição nordestina do romance de 1930, produzindo uma obra estranha e original (Teles 2003: 9) que se utiliza do grotesco como expressão da mudança histórica. Demonstrando consciência das nuances e do caráter estrutural da violência, o autor dá voz àqueles que foram preteridos e apagados pela história, denunciando as oligarquias e desmandos do coronelismo que relegaram uma realidade 'semifeudal' a esses sujeitos esquecidos, abandonados aos ermos e gerais.

Inserida nesse quadro, André Louco é uma novela literária de 47 páginas, com traços regionalistas, que explora o imaginário popular a partir

\footnotetext{
${ }^{1}$ Ressalta-se que a expressão dos conflitos miméticos é determinada historicamente, sendo condicionada pelo modo de produção e reprodução da vida material e pelas contradições sociais que dela decorrem.

${ }^{2}$ Bernardo Élis reagrupou os contos de Ermos e Gerais (1944) e Caminhos e Descaminhos (1965) em dois volumes, respeitando o 'espaço ficcional'. O primeiro, publicado em 1975, sob o título de Caminhos dos Gerais; e o segundo, contendo a novela que deu nome ao livro, intitulado André Louco - edição utilizada no presente artigo.

TradTerm, São Paulo, v.38, fevereiro/2021, p. 291-314

Número Especial - III JOTA

www.revistas.usp.br/tradterm
} 
da figura do louco. Contada em primeira pessoa por um narrador-personagem, utilizando-se de analepse, há "uma distância temporal entre o passado da história e o presente da narração, vazios muitas vezes preenchidos pelas observações do adulto que se faz um narrador menino" (MARCHEZAN 2005: xxv).

Explorando a realidade de uma comunidade interiorana, Bernardo Élis tece uma união coesa entre a linguagem culta e coloquial, na qual cada personagem possui suas idiossincrasias; ${ }^{3}$ destaca-se a estética literária do narrador que não perde o caráter intimista da oralidade.

Por trás de cada conto está a estrutura de [...] um causo, quando não de uma lenda ou de um mito. [...] E é esse sentido de oralidade que determina a ressonância linguística do coloquialismo que marca as falas do narrador e das personagens, já que o espaço entre as duas estâncias se vê praticamente eliminado (TELES 2003: 14).

Plasmando um Brasil mítico, repleto de crendices, medos e lendas folclóricas, o espaço ficcional remonta um pequeno município (anônimo) marcado por uma linha tênue entre a cidade e o campo, com suas instituições estatais em processo de formação. A partir das descrições, costumes e componentes imediatos, é possível inferir que a novela se passa no período entreguerras da primeira metade do século XX. 0 pai do narrador, João Ferreira, conversa com o médico alemão sobre a Grande Guerra. Fala sobre o Comunismo. E em outro momento, relata-se o uso de 'Réis' como unidade monetária, posteriormente substituída pelo Cruzeiro, em 1942: “meu pai não pediu diferença, pagou cinco contos de réis e saiu falando para todo o mundo que pagou somente 200\$000" (ÉLIS 1978: 18).

A construção narrativa apresenta digressões com cortes de cenas que se assemelham a takes cinematográficos. 0 autor estimula nossos sentidos por meio da palavra, trabalhando nosso imaginário ao conceber imagens que se formulam pela oralidade.

Ela costurava, a cabeça inclinada, sua sombra ${ }^{4}$ vacilante projetada disforme na parede, no teto sem forro, e conversava sobre André Louco: que ele matava todo mundo; que ele fizera bramura; que ele ia fugir e estrangular habitante por habitante da cidade (ÉLIS 1978:

\footnotetext{
${ }^{3}$ Essas marcas de oralidade, que variam entre as personagens, estão presentes na película. ${ }^{4} \mathrm{O}$ uso de sombras, como recurso estético, é uma característica importante na composição da iconografia da tradução cinematográfica de Rosa Berardo - ver figura 1.

TradTerm, São Paulo, v.38, fevereiro/2021, p. 291-314

Número Especial - III JOTA

www.revistas.usp.br/tradterm
} 
7, grifo nosso).

Assim, a trama se desenvolve pelo ponto de vista do narradorpersonagem, compondo um relato de caso calcado nas memórias da infância. Essa ótica dita o foco narrativo da novela, que se fixa na dinâmica entre os moradores da comunidade, com destaque para João Ferreira, estabelecendo uma relação periférica da personagem André que permeia a sociedade reverberada pelos ruídos e ecos do imaginário coletivo. Essa perspectiva nos mostra como João direciona seus ressentimentos e recalques para André, apontando-o como o culpado por tudo o que the aflige e buscando disseminar essa ideia para expulsar o Louco do município.

Essas informações são importantes para contextualizar a análise dos estereótipos persecutórios e o modo como a trama nos é apresentada.

Desse modo, João vivia agastado, até eleger sua vítima expiatória:

Por fim, atinou com a causa primária de toda aquela complicação psicológica em que vivia nos últimos tempos - André Louco. Não existisse ele, não haveria espancamento de Pedro, não haveria a sua mendicidade de favores aos jurados, não haveria sua humilhação ante o coronel. Para desabafar, virou-se contra o louco, que passou a bode expiatório.

- Essa cidade é um suplício, ninguém tem descanso. A noite inteira é berreiro de doido. Em toda a parte procuram diminuir o ruído. Aqui existe um cuidado meticuloso em aumentá-lo (ÉLIS 1978: 23).

A partir desse momento, João começa a advogar contra o Louco: “Esse endemoniado, qualquer dia, sai pela rua e será muito bom se não matar alguém" (ÉLIS 1978: 23). Logo em seguida:

um dia, quando o filho do Valentim foi jogar o pacote de 'comê' para o demente, ele deu aquele urro, balançou as grades. O menino confiava nela; já estava habituado com a cena:

- Bamo vê, André véiu! Força!

E não é que a grade cedeu mesmo? O menino correu. Era tarde, porém.

- André Louco fugiu! (ÉLIS 1978: 28-29). ${ }^{5}$

A comunidade se reúne na casa de João para escutar a história, e é nesse momento que ele consegue a atenção desejada; apontando André como o causador de todos os males do lugar. Apesar de conseguir plantar a semente

\footnotetext{
${ }^{5}$ Rosa Berardo recria essa cena (ver figura 8), reinterpretando-a a partir da combinação e síntese. Assim, na película, esse momento se torna o ápice da crise indiferenciadora.

TradTerm, São Paulo, v.38, fevereiro/2021, p. 291-314

Número Especial - III JOTA

www.revistas.usp.br/tradterm
} 
dessa narrativa, as pessoas não se revoltam contra André, mesmo após a morte do filho do Valentim: "Se não fosse o louco não teríamos hoje este prosão animado, - continuava chistoso o dentista” (ÉLIS 1978: 37).

O ápice da crise indiferenciadora, no entanto, ocorre quando alguém grita o nome de 'André Louco' na porta da igreja. Os moradores entram em pânico ao pensar que o louco tinha escapado novamente. Assim, esse malentendido começa a gerar inúmeros conflitos entre os habitantes, até chegar a notícia de que a mulher do escrivão sofreu um aborto ao fugir da igreja: “Foi aí que a revolução de meu pai encontrou clima propício. - Bem que o senhor disse, seu João. É preciso mandar esse tranca embora. Veja quanta discórdia, quanta coisa ridícula" (ÉLIS 1978: 46).

0 crime indiferenciador, ${ }^{6}$ segundo estereótipo, não precisa efetivamente ter sido cometido pelo bode expiatório, visto que ele tem valor simbólico. O foco é atribuir a André a culpa por toda a crise mimética. Assim, há um apontamento genérico: André é a origem de todos os problemas; é o responsável pelo aborto. ${ }^{7}$ Mas, no âmbito pessoal, cada um atribui um crime específico: João culpa André por tudo o que the acontecera com o alemão, Pedro e o coronel Bentinho. Para Joana, “André Louco estava possuído do capeta" (ÉLIS 1978: 38).

Quanto às marcas vitimárias, Girard (2004: 26-27) aponta que a multidão tende a canalizar sua violência às 'minorias', atribuindo-lhes a culpa pela crise mimética. Assim, os traços culturais, religiosos e físicos, como a Loucura e deformações, tendem a polarizar os perseguidores. Pois são traços que diferenciam o bode expiatório da multidão escandalizada.

Por fim, temos o último estereótipo: a violência ou expulsão coletiva. André Louco sofre ambos. Sendo expulso da comunidade e posteriormente morto no sítio de sua família. Conforme Rocha (2017: 59),

\footnotetext{
${ }^{6}$ A crise social, primeiro estereótipo, tende a apagar/misturar as diferenças hierárquicas e funcionais, homogeneizando os sujeitos no plano da violência. Assim, a multidão procura a ação e, não conseguindo identificar ou agir sobre as causas originárias da crise, procura "uma causa acessível e que satisfaça seu apetite de violência" (GIRARD 2004: 23). Nesse sentido, o 'crime indiferenciador' é imputado a um bode expiatório a fim de diferenciar a multidão do 'culpado', unificando o coletivo pelo ódio e violência à vítima expiatória.

7 Percebe-se, aqui, um exemplo de como a determinação histórica condiciona o mecanismo mimético: a morte do filho do Valentim não causou indignação nos habitantes, mas o aborto sofrido pela mulher do escrivão, que possui status social, sim - mesmo que André não tenha sido o responsável pela confusão.
}

TradTerm, São Paulo, v.38, fevereiro/2021, p. 291-314

Número Especial - III JOTA

www.revistas.usp.br/tradterm 
trata-se de mecanismo interno que ao mesmo tempo necessita criar uma exterioridade em relação ao próprio grupo. 0 bode expiatório é um membro do grupo, mas deixa de sê-lo na hora em que é assinalado como culpado da desordem. Converte-se assim numa espécie de elemento externo, favorecendo o retorno da coesão do grupo, que volta a reconhecer-se como unidade, em oposição ao futuro bode expiatório, figura mesma da alteridade que se havia perdido na crise da indiferenciação. ${ }^{8}$

Assim, "André é louco, é pária, é um indivíduo privado de todos os direitos sejam eles religiosos ou sociais e, portanto, excluído da sociedade e aprisionado em sua loucura em contraponto a (in)sanidade social" (CURADO 2016: 347).

\section{A Ótica de Rosa Berardo}

André Louco (1990), de Rosa Berardo, é um curta-metragem (p\&b) em película 35mm, filmado na Cidade de Goiás, com duração de 16:30 min, uma adaptação da novela homônima de Bernardo Élis. O curta foi premiado no Festival de Cinema de Locarno (Suíça), sendo exibido em Gramado; Rio Cine Festival; e no Museu da Imagem e do Som de São Paulo. ${ }^{9}$ A obra estava guardada e jamais havia saído da 'lata' para livre circulação. Assim, com a inserção e disponibilização digital propiciada pela cineasta, finalmente foi possível retomá-la para estabelecer um diálogo com o texto literário, no qual analisamos a transmutação conduzida pela ótica de Berardo.

Ao justapor as obras, constatou-se que o curta-metragem não pleiteou se afastar do texto original, dialogando com o mesmo contexto ficcional e utilizando-se de cenas e falas literais da novela. Atentando-se ao sincretismo semiótico e as demandas do formato empregado, Berardo realizou um recorte

\footnotetext{
80 mecanismo do bode expiatório, ou mecanismo vitimário, "permite que uma comunidade em crise recupere ou preserve seu equilíbrio. Isso é eficaz apenas se a comunidade conseguir dissimular para si mesma a verdadeira natureza do que está fazendo" (KIRWAN 2015: 127), cessando a escalada epidêmica da violência ao transformar a luta de 'todos contra todos' em 'todos contra um', resguardando a coesão do tecido social.

9 Informações disponibilizadas por Rosa Berardo, no vídeo: SOBRE MEU PRIMEIRO FILME, ANDRÉ LOUCO. Disponível em: <https://www.youtube.com/watch?v=SalQy-oh7_g> Acesso 10 jan. 2021.
}

TradTerm, São Paulo, v.38, fevereiro/2021, p. 291-314

Número Especial - III JOTA

www.revistas.usp.br/tradterm 
e rearranjo de símbolos e acontecimentos, transmutando-os em outra "configuração seletiva e sintética" (PlazA 2003: 40). Desse modo, há uma redução da narrativa acrescida de duas cenas inéditas/originais, estabelecendo um plano simbólico sensível ao audiovisual. Esse procedimento corresponde a base da transcriação aplicada por Berardo, pois na tradução intersemiótica

o que se visa é penetrar pelas entranhas dos diferentes signos, buscando iluminar suas relações estruturais, pois são essas relações que mais interessam quando se trata de focalizar os procedimentos que regem a tradução. Traduzir criativamente é, sobretudo, inteligir estruturas que visam à transformação de formas (PLAZA 2003: 71).

Assim, Berardo reafirma as figuras do texto de Élis, acrescentando novos elementos ao (re)interpretá-los e dar-lhes nova forma, manifestando uma "consciência tradutora capaz de perscrutar não apenas os meandros da natureza do novo suporte, seu potencial e limites, mas, a partir disso, dar o salto qualitativo, isto é, passar da mera reprodução para a produção" (PLAZA 2003: 109).

$\mathrm{Na}$ prática, podemos observar esse procedimento logo nos primeiros segundos da película. Replicando a cena inicial da novela, há sons de latidos e o tilintar de correntes, recurso objetivo retirado do texto bernardiano:

ouvi um barulho de corrente se arrastando nas pedras das calçadas, lá fora. A cachorrada latia desesperadamente pela cidade inteira. Os do largo do cemitério latiam e os da rua de baixo respondiam (ÉLIS 1978: 3).

Berardo complementa a cena com o uso de música instrumental não diegética, que auxilia na construção lúgubre e dramática do clima, introduzindo a personagem André Louco de forma indireta, por meio de sombras distorcidas (figura 1); tal como uma assombração entrando na cidade. Observa-se, nas figuras 1 e 2 , a aplicação do contraste de luz e sombras como recurso estético, marcando a mise-en-scène noturna.

TradTerm, São Paulo, v.38, fevereiro/2021, p. 291-314

Número Especial - III JOTA

www.revistas.usp.br/tradterm 
Figura 1: Projeção da sombra de André Louco

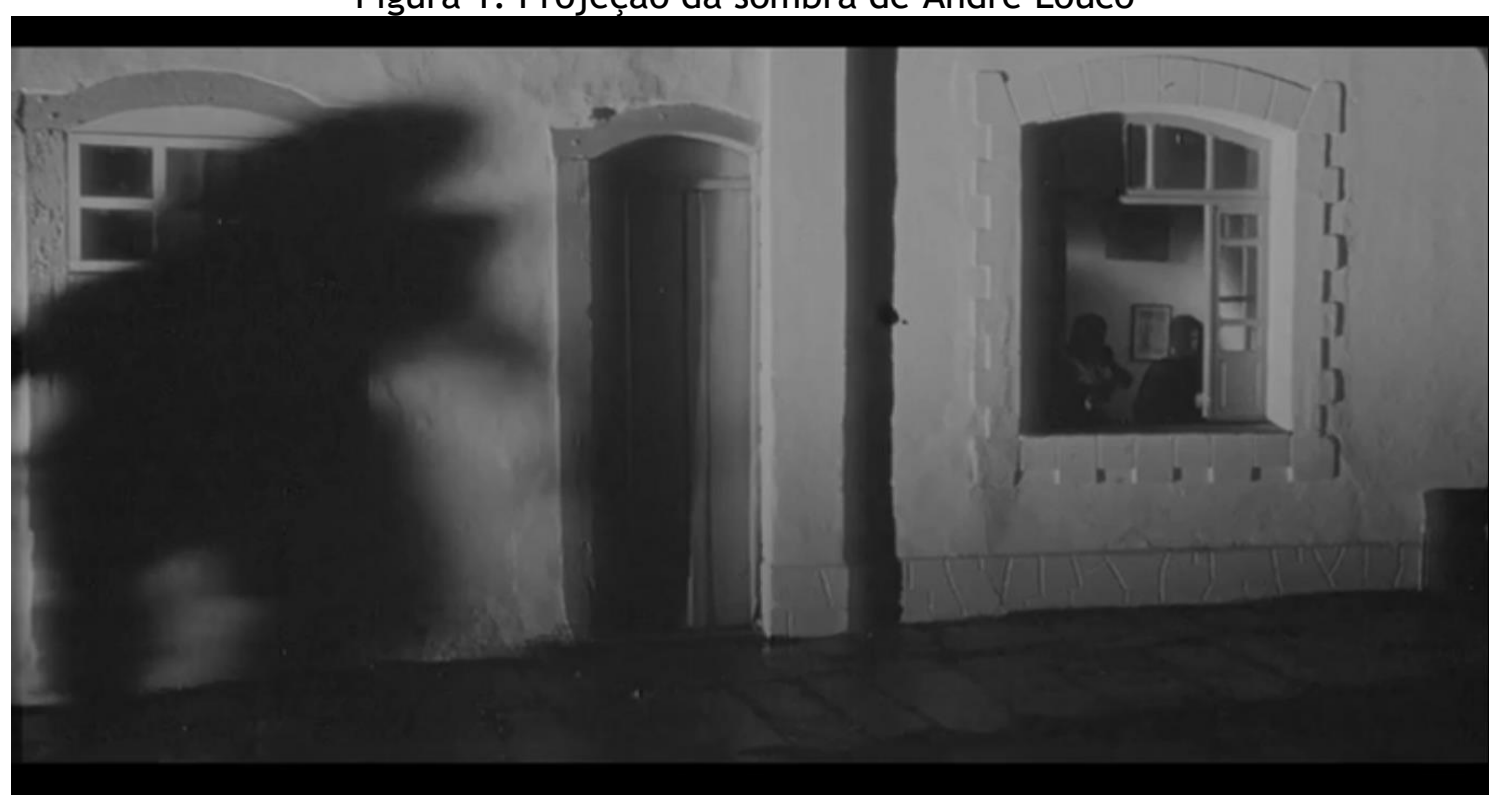

Fonte: André Louco (1990: 01:50/16:30)

Figura 2: Contraste de luz e sombra

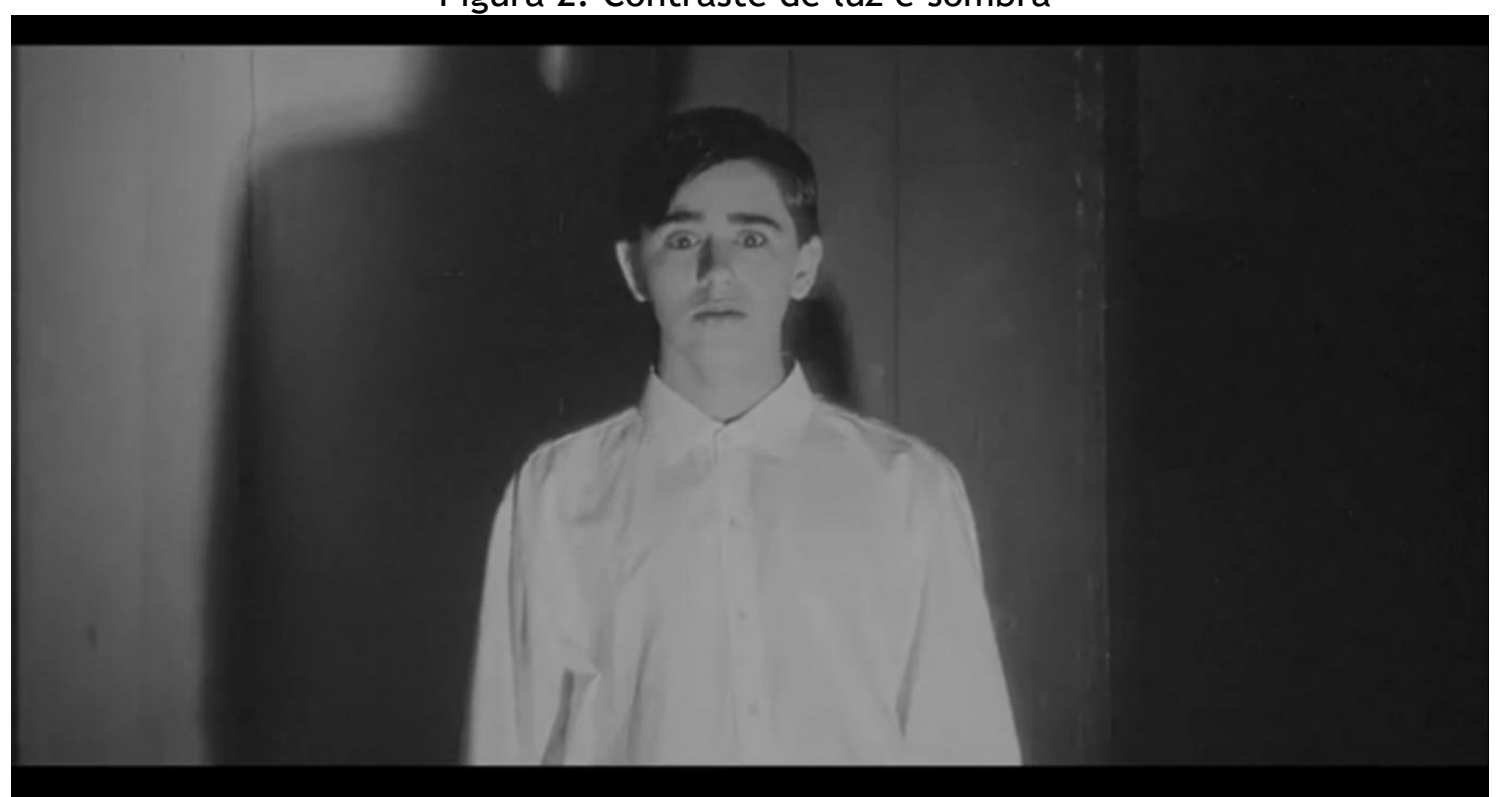

Fonte: André Louco (1990: 01:23/16:30)

O uso de sombras distorcidas, ou em contraste, é pinçado do texto literário, adquirindo uma nova configuração e intencionalidade na película, estando presente em algumas passagens:

TradTerm, São Paulo, v.38, fevereiro/2021, p. 291-314

Número Especial - III JOTA

www.revistas.usp.br/tradterm 
À claridade vermelha e vacilante da fornalha, sua sombra disforme projetava-se na parede enfumaçada e no teto enegrecido, mais impressionante, mais exótico, mais desproporcional.

No nosso quarto, de noite, Joana costurava, augurando desgraças. A sombra dela escorria pelo soalho, dobrava-se na parede, tornava a dobrar-se no teto, onde havia estalidos estranhos (ÉLIS 1978: 49, grifos nossos).

Na composição da tradução, por meio do contraste de luz e sombras, Berardo cria um efeito estético que ambienta a diegese, transmitindo uma percepção de 'atraso e de trevas' de um município rural, sem luz elétrica; compondo uma dualidade entre dia/segurança e noite/terror:

De noite, assombrava a cidade com os urros. No silêncio de desespero da cidade desfalecida de atraso e de trevas, o grito rouco de André acordava assombrações e pesadelos (ÉLIS 1978: 5).

Ao sintetizar esses elementos, a cineasta ressignifica a cena, passando da reprodução à construção de um novo original.

Quanto à estrutura narrativa, observa-se que a perspectiva foi modificada devido à retirada do narrador-personagem, alterando a forma como a trama nos é apresentada. Portanto, não há uso predominante de vozover,$^{10}$ recorrendo-se a ela uma única vez como recurso para desenvolver um flashback de André. Assim, as personagens João, Antão e o sacristão assumem, brevemente, o papel de narrador, mantendo uma coesão narrativa entre os cortes.

O texto literário aborda vários acontecimentos do passado de André, nem sempre confiáveis. Desse modo, Berardo decide contar apenas um desses casos, utilizando-se de um trecho literal da novela, ${ }^{11}$ substituindo a voz do narrador-personagem por um diálogo, em voz-over, entre as três personagens citadas acima. Em seguida, há uma cena inédita na qual André faz um discurso em um curral, cercado por vacas (Figura 3).

\footnotetext{
10 Usamos o termo voz-over de acordo com Xavier (2003: 68).

11 "André, desde mocinho, tinha um gênio insuportável [...] Deu no delegado, nos bate-paus, saiu pelas ruas dando tiros nas paredes. Todo mundo fechou as portas" (ÉLIS 1978: 4).

TradTerm, São Paulo, v.38, fevereiro/2021, p. 291-314

Número Especial - III JOTA

www.revistas.usp.br/tradterm
} 
Figura 3: Discurso de André

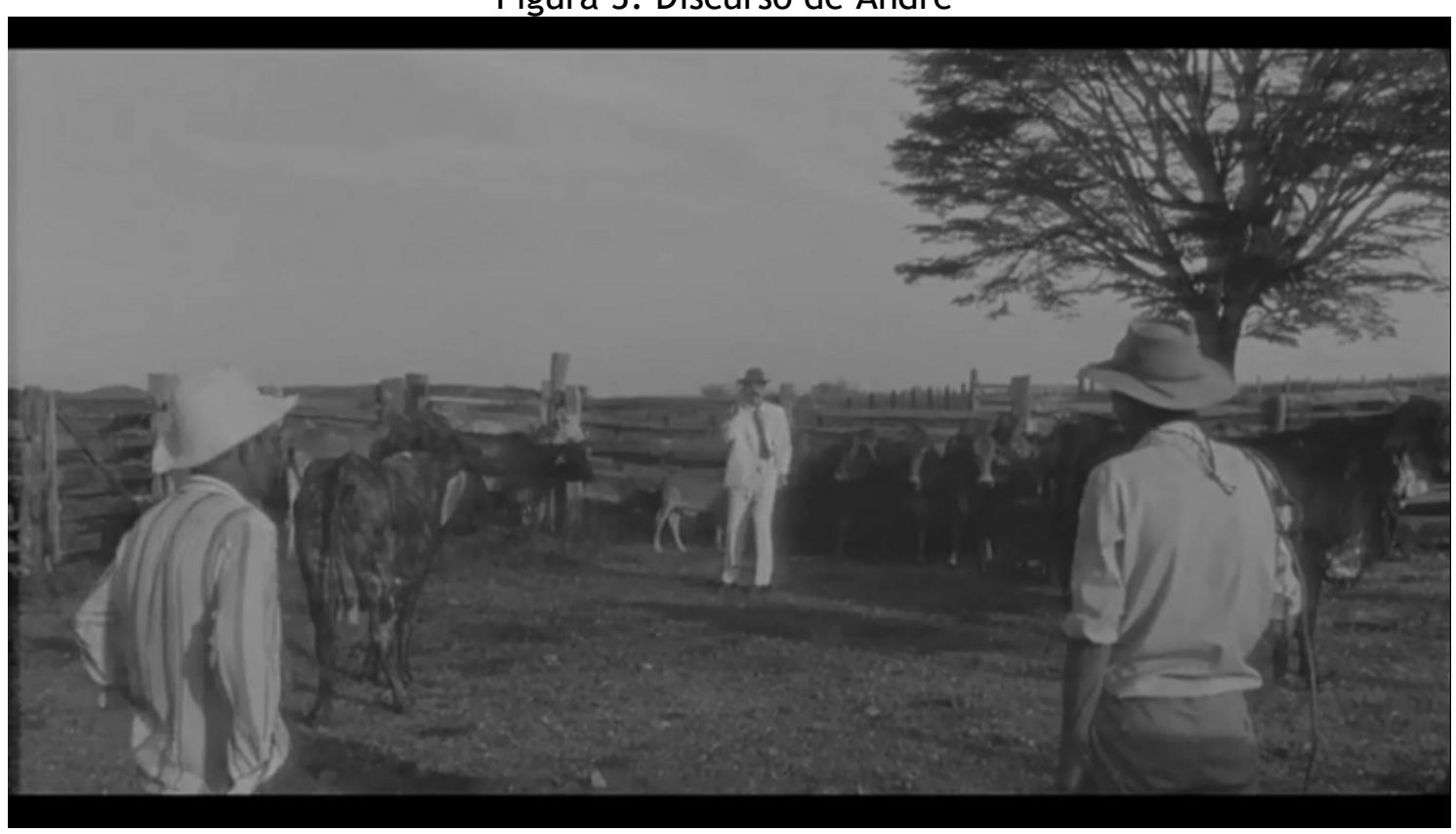

Fonte: André Louco (1990: 03:27/16:30)

Essa cena, elaborada e criada exclusivamente para o curta-metragem, apresenta o momento exato em que André enlouquece, sendo preso por querer “distribuir o [gado] que não tem", como afirma o delegado. Ensandecido, André produz um discurso aparentemente sem nexo, mas que remete à denúncia do coronelismo e exploração do trabalho.

Há uma construção simbólica por trás da decupagem e ações da personagem. Enquanto discursa, André começa a se despir, arremessando o chapéu pelos ares (figura 4). Aqui, as roupas representam as amarras e laços sociais, os acordos tácitos entre os indivíduos, a sanidade e racionalidade que nos permite viver em sociedade. Há um rompimento claro da personagem com o tecido da malha social, o diruir psicológico que abraça a loucura, tornandose um sujeito imprevisível e de difícil convívio. $\mathrm{E}$, por isso mesmo, incômodo. Assim, André Louco incomoda, mas produz fascínio: “Precisamos do louco, seu João. Precisamos muito dele. Sem o louco, ninguém aguenta a insipidez da cidade" (ÉLIS 1978: 37). ${ }^{12}$

\footnotetext{
${ }^{12}$ Frase reproduzida na película, aos 08:29 min.

TradTerm, São Paulo, v.38, fevereiro/2021, p. 291-314

Número Especial - III JOTA

www.revistas.usp.br/tradterm
} 
Figura 4: André arremessando o chapéu

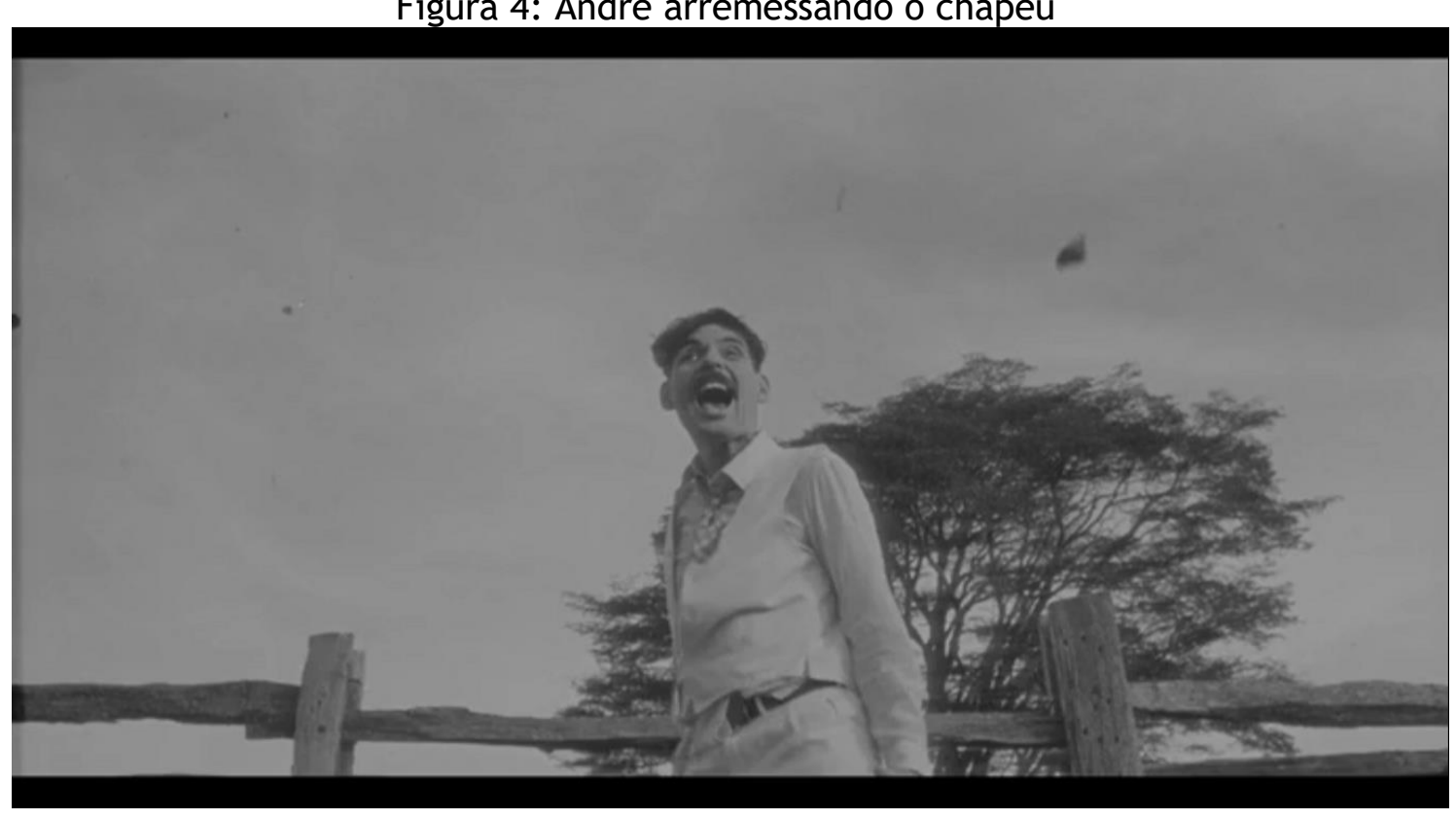

Fonte: André Louco (1990: 03:44/16:30)

Em seguida, há um corte de cena, saltando para o delegado na cadeia. Se no momento anterior André se despia e arremessava o chapéu pelos ares, agora a película nos mostra o delegado pegando o chapéu na mesa (Figura 5), finalizando o plano simbólico ao 'restabelecer' a ordem: sendo André uma voz incômoda à sociedade, cabe às instituições coercivas do Estado calá-lo, segregando-o do convívio social.

Figura 5: Chapéu do Delegado

TradTerm, São Paulo, v.38, fevereiro/2021, p. 291-314

Número Especial - III JOTA

www.revistas.usp.br/tradterm 


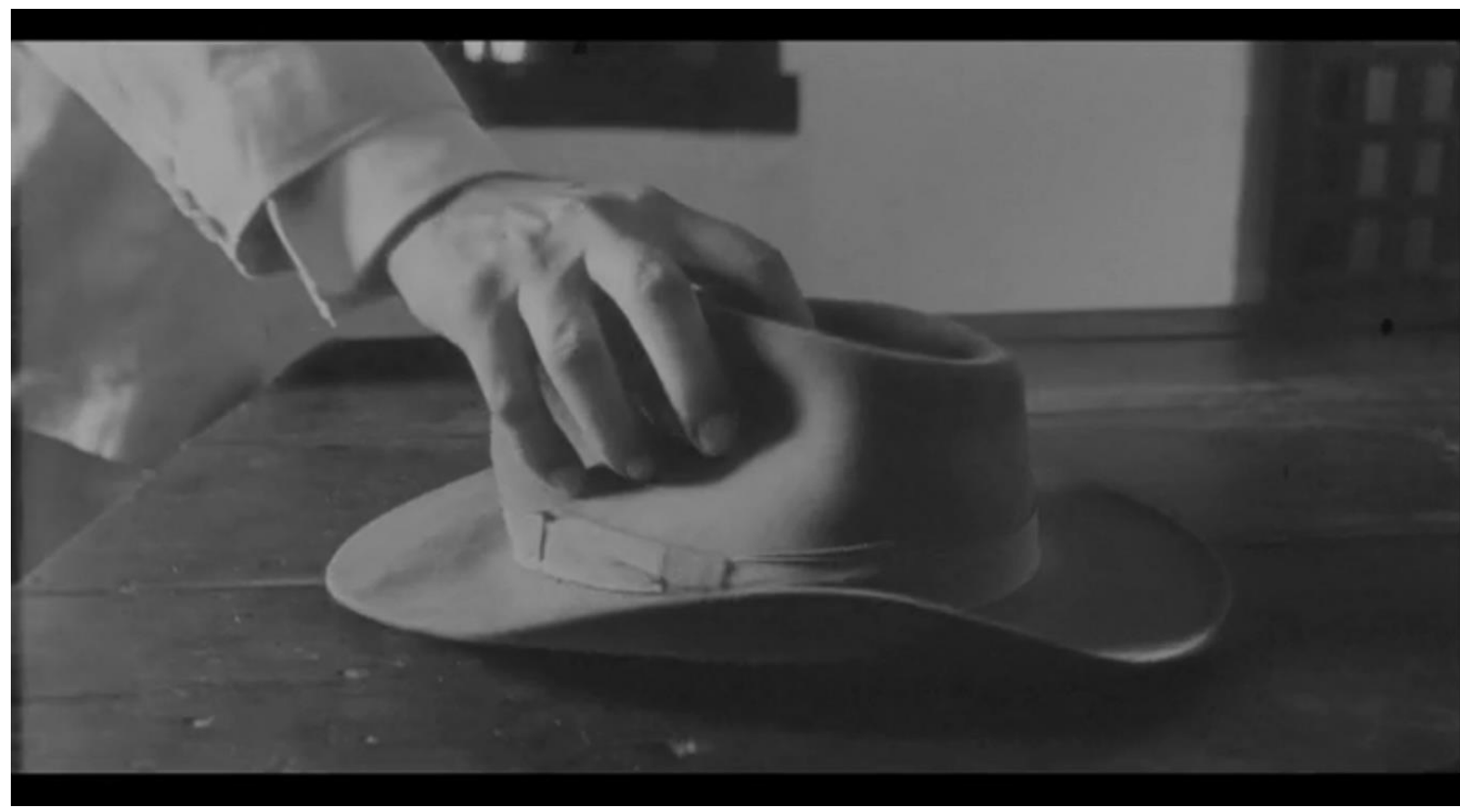

Fonte: André Louco (1990: 03:45/16:30)

Assim, Berardo segue um padrão ao pinçar trechos da novela, mesclando-as para produzir novos significados. Ao transpor os diálogos do texto, a cineasta mantém as marcas de oralidade, transmitindo o pensamento, nível de escolaridade e visão de mundo pessoal de cada personagem. Seja o religioso, científico ou mítico.

Próximo ao desfecho que leva a expulsão de André, Berardo ressignifica o diálogo entre o filho de João e a empregada Joana (figura 6), construindo um novo significado ao unir a passagem: “Joana começou a soprar o ferro, na janela, para avivar as brasas, e voltou à conversa” (ÉLIS 1978: 23), ao diálogo:

- Joana, se ele fugir, acha que ele vem aqui em casa?

- Ele quem? André Louco?

- É.

- Ora, se évem! Évem, mas é feito cobra mandada. Seu pai mandô botá ele no pote (ÉLIS 1978: 7).

Essa combinação nos antecipa que algo está para acontecer. Desse modo, após o diálogo, o filho de João pula a janela para seguir o menino que levava o almoço aos presidiários, incluindo André. Nesse momento, Joana encara o horizonte, torpe, como se pressentisse algo, um presságio; queimando a roupa com o ferro de passar (figura 7).

Figura 6: Joana e o filho de João

TradTerm, São Paulo, v.38, fevereiro/2021, p. 291-314

Número Especial - III JOTA

www.revistas.usp.br/tradterm 


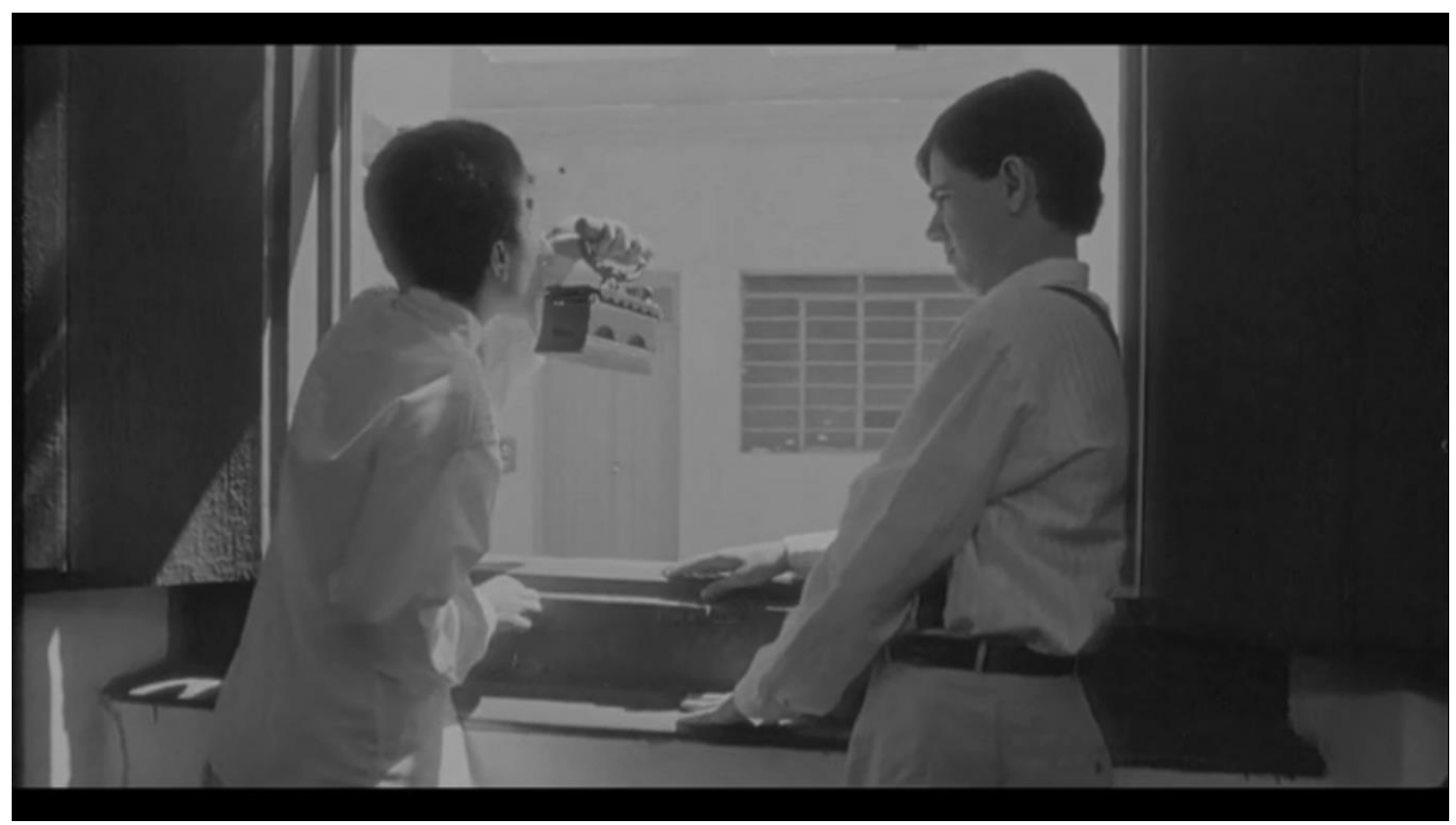

Fonte: André Louco (1990: 05:16/16:30)

Figura 7: Joana tendo um presságio

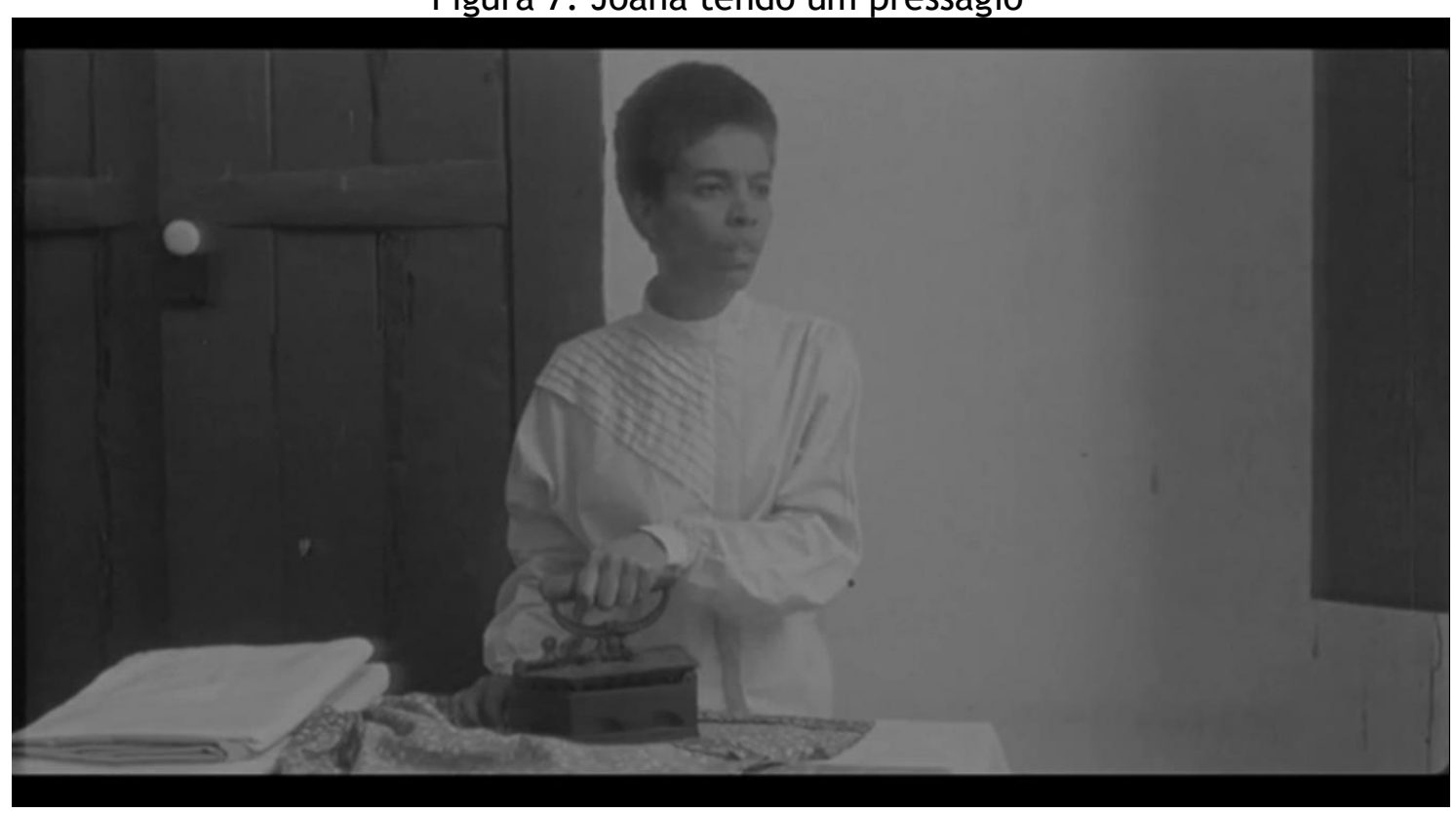

Fonte: André Louco (1990: 05:52/16:30)

O menino joga a marmita de André pela fresta da janela, provocando o louco. Com feições animalescas (figura 8), André ataca, arrancando a grade e fugindo da prisão. Dessa maneira, Berardo combina essa cena com o ápice da crise indiferenciadora do texto literário (quando alguém grita o nome de André Louco na porta da igreja, assustando as pessoas). Aqui, no entanto, é o filho de João que avisa os moradores.

TradTerm, São Paulo, v.38, fevereiro/2021, p. 291-314

Número Especial - III JOTA

www.revistas.usp.br/tradterm 
Figura 8: André Louco comendo

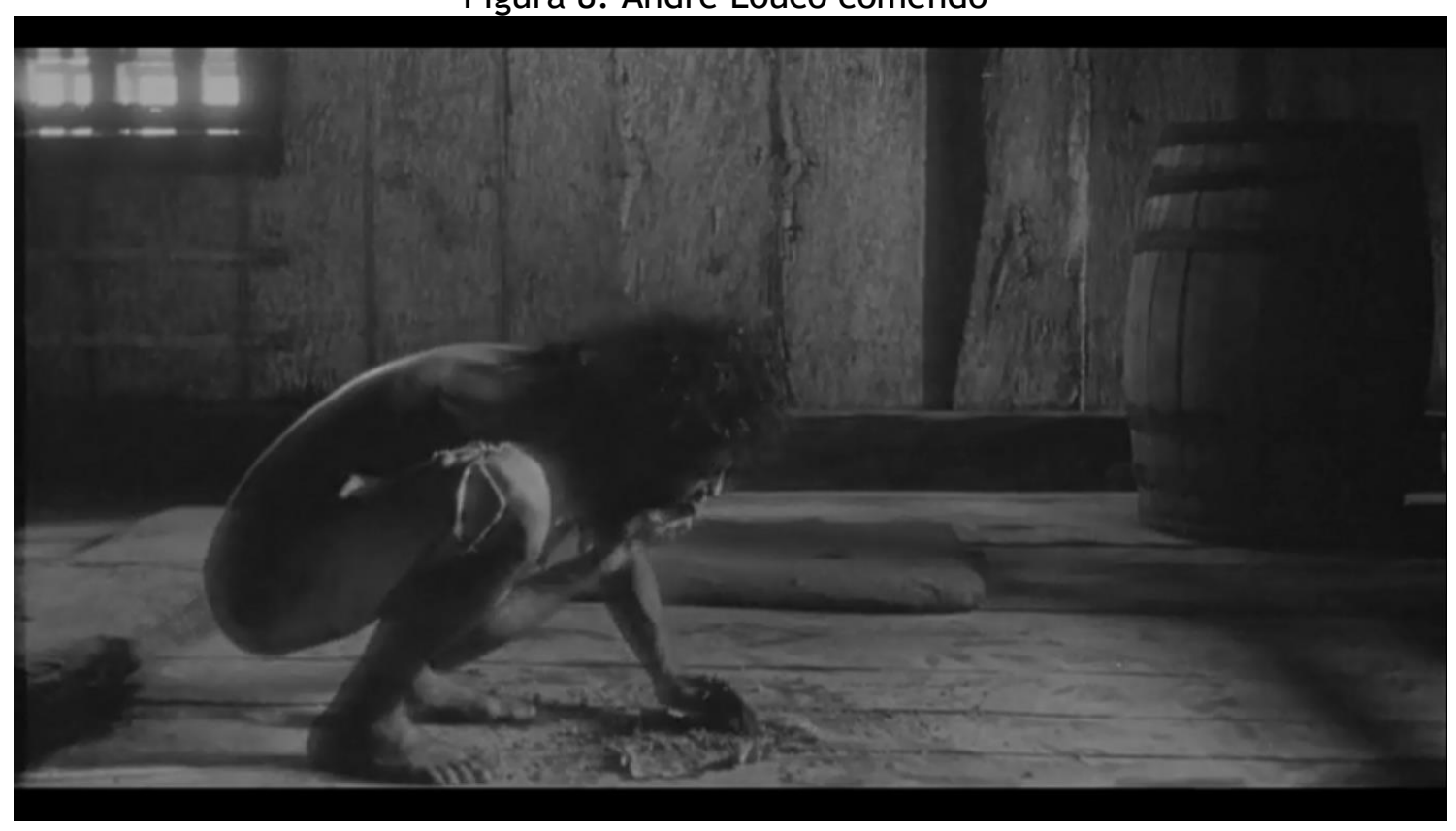

Fonte: André Louco (1990: 06:42/16:30)

Se a novela desenvolve pequenas tramas para mostrar como João (e a comunidade) concebe o louco como um bode expiatório, na película, Berardo não se propõe a construir essa dinâmica; direcionando a câmera para André e sua jornada. Todavia, utilizando-se de um dos conflitos de Antão, a cineasta sintetiza o modo como direcionamos nossos ressentimentos em forma de violência. Expondo, assim, que todos nós temos nossos bodes expiatórios.

Enquanto Antão se escondia na igreja, verificando se o louco não estava por perto, Sá Maria o chama, assustando-o (figura 9). Ressentido por perder a pose de valente, ele canaliza e transforma esse sentimento em violência contra André Louco. Desse modo, Berardo recorta um fato da novela e o transforma, criando outra cena original (figura 10).

Após fugir da prisão, a comunidade expulsa André, e é Antão que o leva para fora da cidade. Ao atravessarem um rio, Antão afoga o louco, gargalhando e repetindo: “Quem é que tem medo de louco?”.

Figura 9: Antão se assustando

TradTerm, São Paulo, v.38, fevereiro/2021, p. 291-314

Número Especial - III JOTA

www.revistas.usp.br/tradterm 


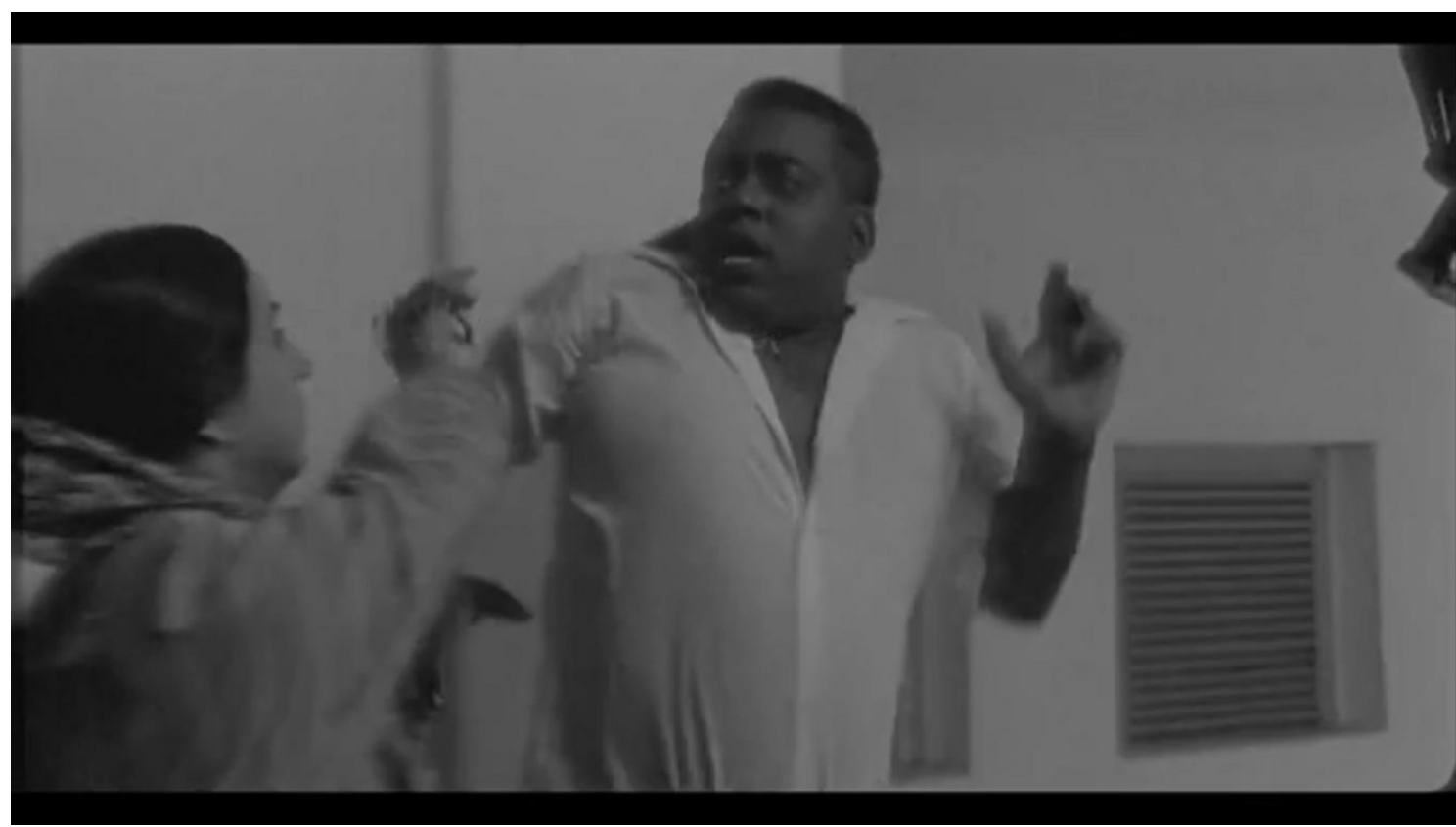

Fonte: André Louco (1990: 07:44/16:30)

Figura 10: Antão afogando André

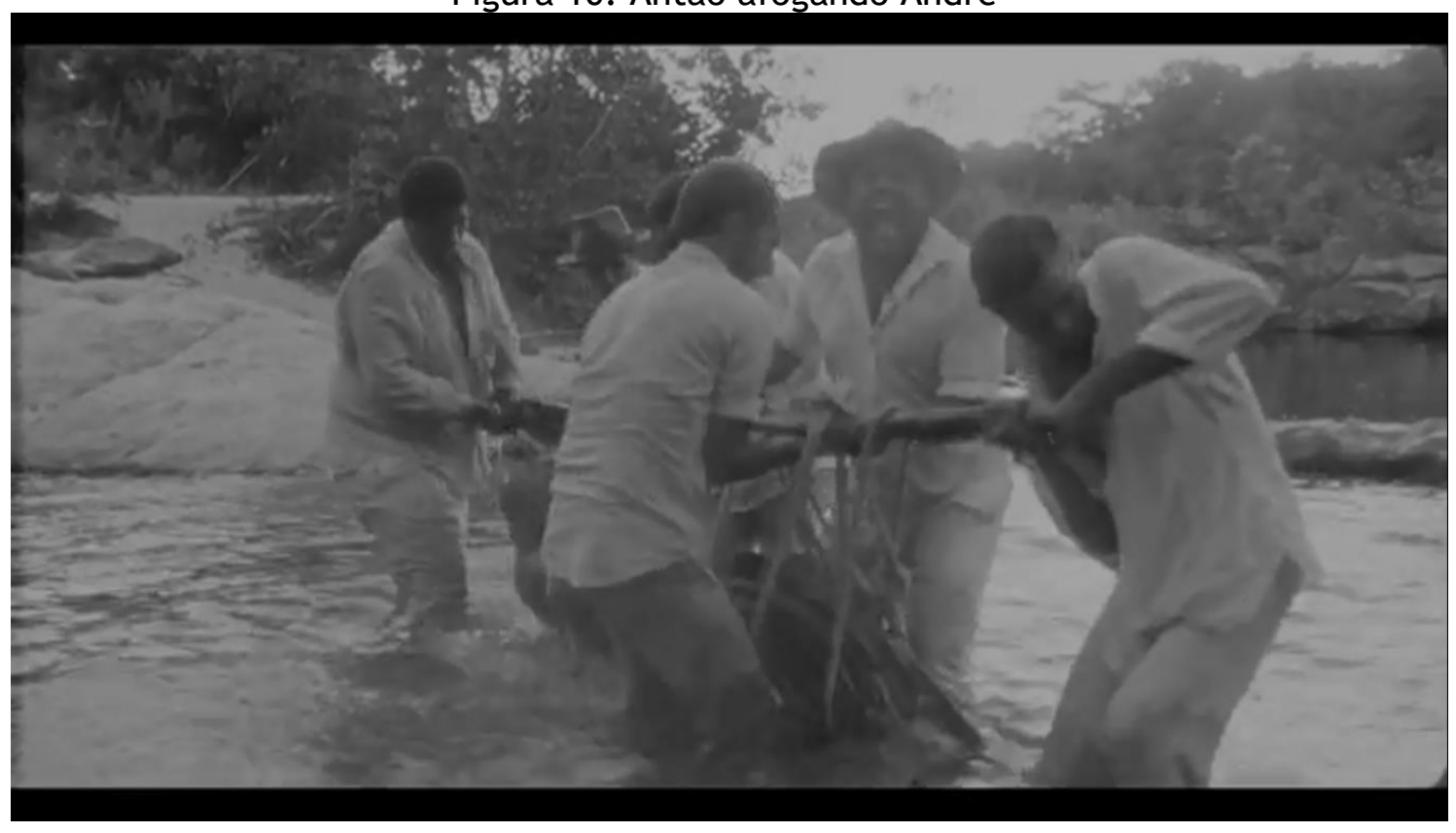

Fonte: André Louco (1990: 10:24/16:30)

André é levado para um sítio, sendo acorrentado ao tronco e

TradTerm, São Paulo, v.38, fevereiro/2021, p. 291-314

Número Especial - III JOTA

www.revistas.usp.br/tradterm 
abandonado (figura 11). Ressalta-se que há uma ruptura narrativa, quebrando a coesão, pois em nenhum momento temos informação sobre o lugar e as pessoas que ali estão, ou qual a conexão delas com André Louco. Essa lacuna propicia certa confusão caso o receptor não tenha lido a novela a priori. Situação que se agrava após a chegada da comitiva; visto que André é içado na cozinha, preso a um colete de couro, dando início a um processo de tortura movido pela ignorância. Maltratado e com os ferimentos expostos às moscas, um dos homens conclui que André está 'entupido de demônio'. Juntos, jogam creolina nas feridas do louco. Urrando de dor e içado pelo colete de couro, André se debate em "polichinelos diabólicos", até cessar.

“- As bichera tá tudo morta - exclamou o baiano. E com elas, André. Santo André Louco, mártir, orai por ele” (ÉLIS 1978: 49).

Figura 11: André Louco acorrentado ao tronco

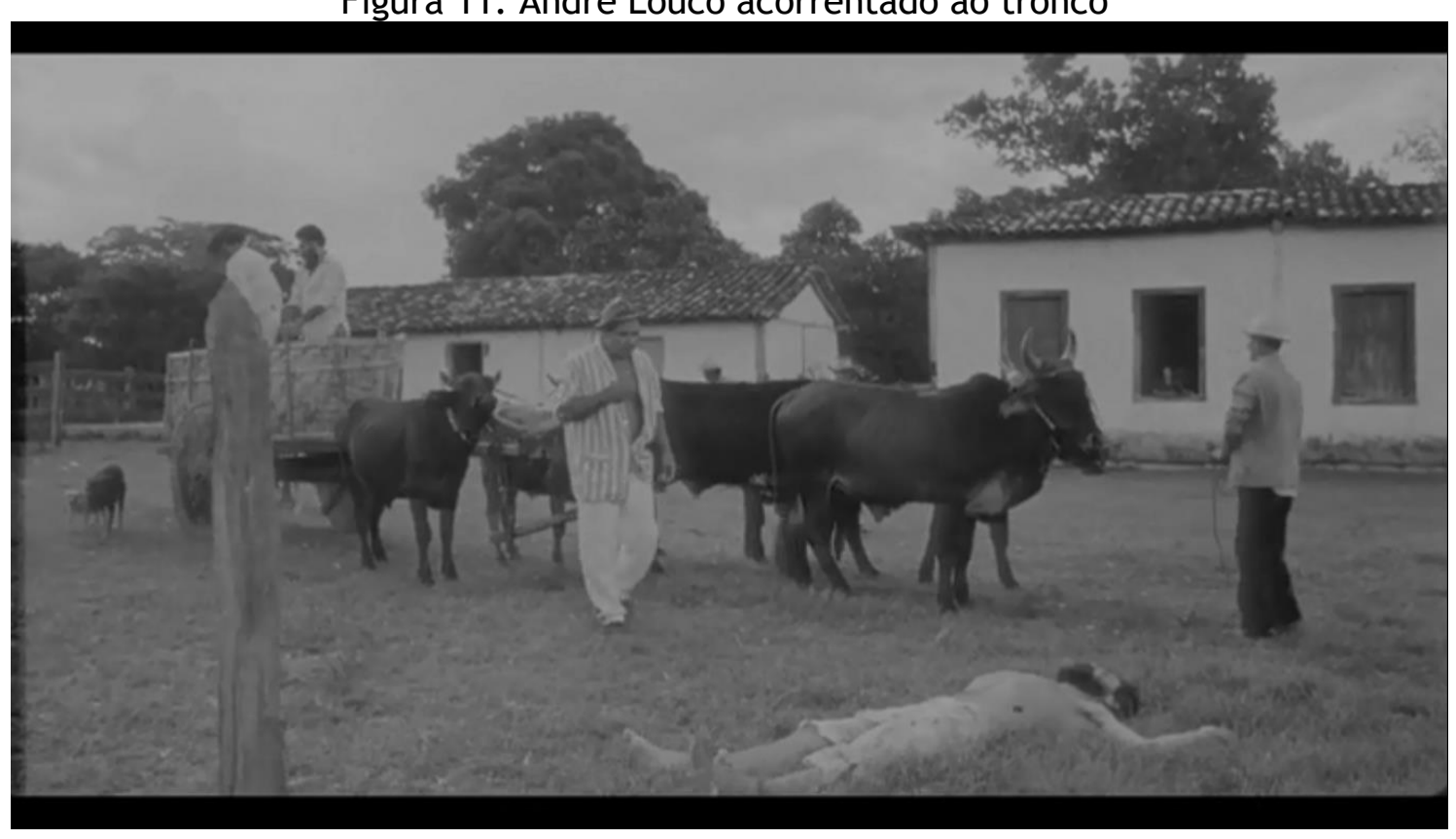

Fonte: André Louco (1990: 11:41/16:30)

E se é por meio de sombras distorcidas e ângulos indiretos que André TradTerm, São Paulo, v.38, fevereiro/2021, p. 291-314

Número Especial - III JOTA

www.revistas.usp.br/tradterm 
nos é apresentado, também é dessa forma que ele se retira e morre ao final da película (figura 12).

Figura 12: Morte de André

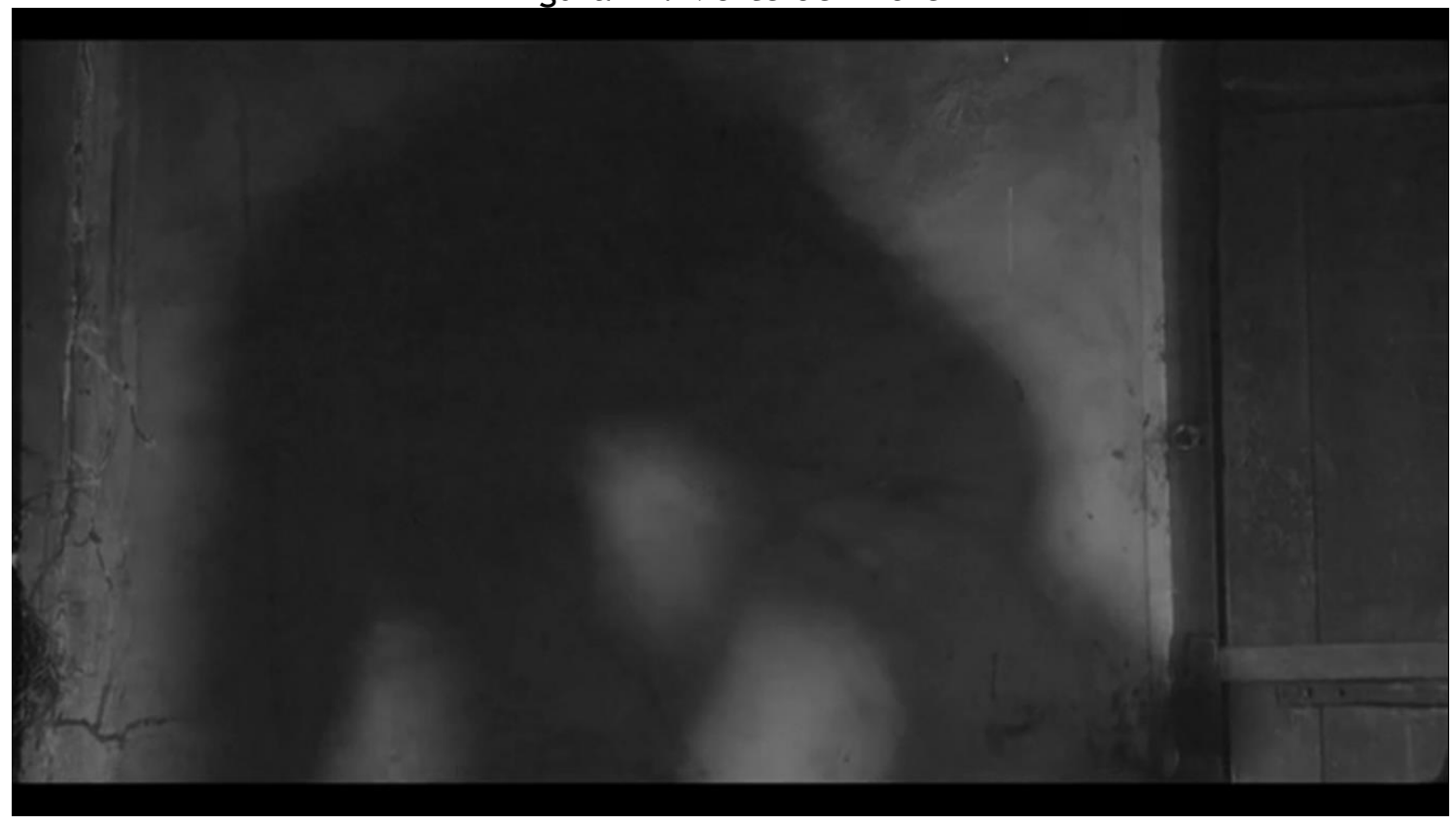

Fonte: André Louco (1990: 14:45/16:30)

Apesar de apresentar dois estereótipos imediatos (as marcas vitimárias e a violência/expulsão coletiva), Berardo utiliza-se de outro foco narrativo ao realizar a transmutação, negligenciando a construção da crise da indiferenciação. Portanto, a câmera se direciona para a personagem André em detrimento das interações sociais da comunidade, buscando a catarse na exposição da fragilidade humana. Nesse aspecto, Rosa Berardo se recusa a transpor uma realidade maniqueísta redutora, desenvolvendo uma percepção para além do bem e do mal; expondo a banalidade da violência social, a qual todos compartilhamos em algum grau - seja por dinâmicas miméticas situacionais ou pela reprodução da violência intrínseca às estruturas de poder, condicionadas pelo modo de produção da vida material.

Quanto ao terceiro estereótipo (crime indiferenciador), pode-se argumentar que a morte do filho do Valentim se enquadra. Mas a película não visa se aprofundar nesse debate. Assim, há uma crise, um crime, uma indicação de conflito social e intui-se que André é o culpado por tudo. Dinâmica exemplificada no ressentimento e vingança de Antão.

TradTerm, São Paulo, v.38, fevereiro/2021, p. 291-314

Número Especial - III JOTA

www.revistas.usp.br/tradterm 


\section{Considerações finais}

0 processo de tradução intersemiótica exercido por Rosa Berardo pauta-se no texto literário, realizando um recorte e rearranjo de signos. Dessa forma, ela (re)cria outro original a partir da combinação e síntese, seja entre cenas da novela ou entre um recorte factual e uma proposta criativa dialógica, concebendo novos símbolos e significados.

0 texto bernardiano é um ensaio sobre as interações sociais de uma comunidade interiorana do Brasil e de como seus habitantes reagem à presença de André, um homem mentalmente instável; enquanto a película desenvolve um caráter sintético, com enfoque na construção da imagem e martírio do louco.Essa divergência do foco narrativo está relacionada à retirada do narrador-personagem, alterando o ponto de vista segundo a intencionalidade de cada autor. Cabe ressaltar que "a fidelidade ao original deixa de ser o critério maior de juízo crítico, valendo mais a apreciação do filme como nova experiência que deve ter sua forma, e os sentidos nela implicados, julgados em seu próprio direito" (XAVIER 2003: 62). Isso significa que a tradução deve criar seu próprio mundo ficcional autossustentável, uma vez que "a operação tradutora como trânsito criativo de linguagens nada tem a ver com fidelidade, pois ela cria sua própria verdade [...] onde se processa o movimento de transformação de estruturas e eventos" (PlAZA 2003: 1). Portanto, "ao cineasta o que é do cineasta, e ao escritor o que é do escritor" (XAVIER 2003: 62).

Ampliando a discussão, temos que o bode expiatório girardiano constitui-se da canalização da violência coletiva contra um indivíduo ou grupo específico, atribuindo-lhe a responsabilidade pela crise social. Destarte, tanto a novela quanto a tradução cinematográfica apresentam o mecanismo do bode expiatório, apesar de divergirem na forma de explorar as interações sociais.

A novela contextualiza e desenvolve os conflitos miméticos, explorando todos os estereótipos persecutórios do bode expiatório. A película, no entanto, renuncia à construção dos estereótipos em detrimento de outra perspectiva do foco narrativo.

Assim, a ótica de Berardo possui divergências da novela literária, mas

TradTerm, São Paulo, v.38, fevereiro/2021, p. 291-314

Número Especial - III JOTA

www.revistas.usp.br/tradterm 
sustenta-se por si só (apesar da ruptura narrativa no plano final), explorando novas configurações a partir das especificidades semióticas de sua mídia. 


\section{Agradecimentos}

O presente trabalho foi realizado com apoio do Conselho Nacional de Desenvolvimento Científico e Tecnológico (CNPq). Agradeço, também, à professora Doutora Maria Eugênia Curado pelas orientações, conselhos e inúmeras contribuições.

\section{Referências}

AMORIM, M. A. Da tradução intersemiótica à teoria da adaptação intercultural: estado da arte e perspectivas futuras. Itinerários, n. 36, p. 15-33, jan./jun. 2013.

BrasileEIRO, A. M. M. Manual de produção de textos acadêmicos e científicos. São Paulo: Editora Atlas, 2013.

Carvalhal, T. F. Literatura Comparada. 10 ed. São Paulo: Ática, 2006.

CURADO, M. E. André louco: violência e brutalidade na representação do bemestar social. Revista Plurais, vol. 6, n. 2, p. 335-349, jul./dez. 2016.

ÉLIS, B. André Louco [1944]. In: ÉLIS, B. André Louco: contos. Rio de Janeiro: José Olympio, 1978: 3-49.

GIRARD, R. O bode expiatório. Trad. Ivo Storniolo. São Paulo: Paulus, 2004.

GIRARD, R. Mentira romântica e verdade romanesca. Trad. Lilia Ledon da Silva. São Paulo: É realizações, 2009.

GIRARD, R. La violencia y lo sagrado. Trad. Joaquín Jordá. $5^{\circ}$ ed. Barcelona: Anagrama, 2012.

HAMERTON-KelLy, R. G. Violência sagrada, desejo deformado e o mecanismo do bode expiatório: a teoria de René Girard. In: HAMERTON-KeLLY, R. G. Violência sagrada: Paulo e a hermenêutica da cruz. Trad. Maurício G. Righi. São Paulo: É Realizações, 2012: 45-88

Jakobson, R. Linguística e comunicação. Trad. Izidoro Blikstein e José Paulo Paes. $19^{\circ}$ ed. São Paulo: Cultrix, 2003 [1969].

KIRWAN, M. Teoria Mimética: conceitos fundamentais. Trad. Ana Lúcia Correia da Costa. São Paulo: É Realizações, 2015.

Marchezan, L. G. (Prefácio). In: ÉlIS, B. Ermos e Gerais. São Paulo: Martins Fontes, 2005.

TradTerm, São Paulo, v.38, fevereiro/2021, p. 291-314

Número Especial - III JOTA

www.revistas.usp.br/tradterm 
PlaZA, J. Tradução intersemiótica. São Paulo: Perspectiva, 2003.

PelLegrinI, T. Narrativa verbal e narrativa visual: possíveis aproximações In: PellegRINI, T. et al. Literatura, cinema e televisão. São Paulo: Editora Senac, 2003.

RochA, J. C. C. Culturas shakespearianas: teoria mimética e os desafios da mímesis em circunstâncias não hegemônicas. São Paulo: É Realizações, 2017.

Teles, G. M. A síntese su/realista de Bernardo Élis. In: ÉLIS, B. Melhores contos: Bernardo Élis. $3^{\circ}$ ed. São Paulo: Global, 2003.

XAVIeR, I. Do texto ao filme: a trama, a cena e a construção do olhar no cinema. In: PellegrinI, T. et al. Literatura, cinema e televisão. São Paulo: Editora Senac, 2003.

\section{Filmografia}

ANDRÉ Louco. Direção: Rosa Berardo. Cidade de Goiás: Orion Cinema e Vídeo e CPCE/UnB, 1990. 16:30 min. Son. p\&b, curta-metragem em película 35mm. Disponível em: <https://vimeo.com/236498928> Acesso em: 12 jan. 2021.

Recebido em: 15/03/2020

Aceito em: 19/01/2021

Publicado em fevereiro de 2021

TradTerm, São Paulo, v.38, fevereiro/2021, p. 291-314

Número Especial - III JOTA

www.revistas.usp.br/tradterm 